\title{
Oribatid mites (Acari, Oribatida) of bushy patches in steppe vegetation of cape Tarkhankut in Crimea (Ukraine)
}

\author{
STANISŁAW SENICZAK ${ }^{1}$, SŁAWOMIR KACZMAREK ${ }^{2}$ and ANNA SENICZAK ${ }^{1}$ \\ ${ }^{1}$ Department of Ecology, University of Technology and Life Sciences, Kordeckiego 20, \\ 85-225 Bydgoszcz, Poland \\ ${ }^{2}$ Department of Zoology, Kazimierz Wielki University, Ossolińskich 12, 85-092 Bydgoszcz, Poland \\ Corresponding author: Stanisław Seniczak, stseni@utp.edu.pl
}

(Received on 29 March 2011; Accepted on 1 August 2011)

\begin{abstract}
The density, species number, and age structure of oribatid mites were investigated in bushy patches (elm, hawthorn, hawthorn with rose) in steppe vegetation of cape Tarkhankut (Crimea). In these patches, the density of mites in shrub litter, herbs and moss was higher, but species number was similar like in open steppe vegetation. Hawthorn increased the density distinctly more than hawthorn with rose or bushy elms. In bushy patches, the samples of moss were richer in mites than samples of shrub litter alone or with herbs. Among oribatid mites, Chamobates c.f. spinosus and Trhypochthonius tectorum were most abundant, but relatively abundant and common were also Tectocepheus velatus, Oribatula sp. 1, Achipteria nitens, and Brachychthonius berlesei. In oribatid mite communities, adults dominated, but the age structure of populations greatly depended on vegetation type.
\end{abstract}

Keywords: Crimea, Tarkhankut, bushy patches, Oribatida, juveniles

\section{INTRODUCTION}

Oribatid mites in steppe vegetation of Crimea Peninsula are still known insufficiently, and the investigations concern mainly zoogeographical and faunistic aspects (Gordeeva 1973, 1980, 1983; Karppinen et al. 1987; GordeEva \& Karppinen 1988; GordeEva et al. 1998). This fauna is relatively rich, but only few species achieve a higher density and dominance index there (SENICZAK et al. 2009). This makes the area interesting for ecological research on populations of oribatid species, including their age structure.

The density and species number of mites highly depend on vegetation type (RAJski 1967, 1968). Crimean Peninsula is covered by steppe vegetation and has a Mediterranean climate, with a warm or hot season (May-October, $23-25^{\circ} \mathrm{C}$, total precipitation $290 \mathrm{~mm}$ ), and a cool season (November-April, 5-14 ${ }^{\circ} \mathrm{C}$, total precipitation $490 \mathrm{~mm}$ ), with 250-300 sunny days per year. However, a fresh sea breeze slightly 
lowers the coastal temperature and increases air humidity, increasing the density of oribatid mites (SENICZAK et al. 2009). The patches of bushes additionally protect the vegetation and soil against intensive solar radiation, improving the living conditions for mites. The steppe oribatid fauna is influenced by geographic expansion of species from the Mediterranean region, Middle Asia and Europe.

In this paper we investigated the density and species composition of oribatid mites in selected microhabitats of bushy patches with elm trees, hawthorn, and hawthorn with rose, on cape Tarkhankut (Crimea), with particular reference to the age structure of some species, which is rarely investigated in acarological papers from that region.

\section{MATERIAL AND METHODS}

Samples of $500 \mathrm{~cm}^{3}$ each were taken on 15-20 July 2004, in 3 replicates, from the following microhabitats under steppe bushes: (1) herbs under elm bushes (Ulmus sp.); (2) herbs, moss, and shrub litter alone under hawthorn (Crataegus pojarcoviae L.); and (3) herbs under hawthorn with rose (Rosa sp.). Obviously, the litter of herbs was partly mixed with leaves and other organs shed by the shrubs growing above them.

The mites were extracted in Tullgren funnels, and next conserved and determined to species or genus, including juveniles. In total, 40404 individuals were investigated. Oribatid species were characterized with the abundance $(A)$ and dominance $(D)$ indices, while the mite communities were compared with the Shannon index $H^{\prime}$ (ODUM 1971). Names of oribatid species follow SuBíAs (2004, online version 2011) and partly WeIGMANN (2006).

\section{RESULTS}

The herbs, moss, and shrub litter in bushy patches of steppe vegetation of cape Tarkhankut were rather rich in oribatid mites, but their density greatly depended on vegetation type. Most oribatid mites preferred the hawthorn patches, where the den-

Table 1. Characteristics of oribatid mite communities in selected microhabitats under steppe bushes of Crimea: mean density (individuals per sample, i. e. $500 \mathrm{~cm}^{3}, n=3$ ), number of species, and Shannon index of diversity $\left(H^{\prime}\right)$

\begin{tabular}{|c|c|c|c|c|c|}
\hline \multirow{2}{*}{ Community parameters } & \multirow{2}{*}{$\begin{array}{l}\text { Elm, } \\
\text { herbs }\end{array}$} & \multicolumn{3}{|c|}{ Hawthorn } & \multirow{2}{*}{$\begin{array}{l}\text { Hawthorn+ } \\
\text { rose, herbs }\end{array}$} \\
\hline & & herbs & moss & litter alone & \\
\hline Mean density of Oribatida & 515 & 1646 & 7484 & 2487 & 1336 \\
\hline $\begin{array}{l}\text { Mean density of juvenile } \\
\text { Oribatida }\end{array}$ & 114 & 974 & 4050 & 837 & 534 \\
\hline Number of species of Oribatida & 32 & 28 & 28 & 32 & 33 \\
\hline Shannon index $H$ 'of Oribatida & 2.42 & 2.11 & 1.40 & 1.94 & 2.29 \\
\hline
\end{tabular}


sity was 3.2-fold higher, or hawthorn with rose, where it was 2.6-fold higher than in elm patches. Considering the types of samples, in moss the density was 4.5 -fold higher, and in shrub litter alone it was 1.5 -fold higher than in the litter alone of herbs mixed with shrub litter (Table 1).

In most microhabitats, the number of species of oribatid mites was similar (3233 species), except for herbs and moss in hawthorn, where it was lower (Table 1). In oribatid mite communities, 3-4 species were abundant, and therefore the Shannon index $H^{\prime}$ 'was rather low; it achieved the highest value in herbs under elm bushes, and the lowest value in moss.

In the investigated bushy patches, the most abundant were Chamobates c.f. spinosus Sellnick, 1928, and Trhypochthonius tectorum (Berlese, 1896), especially in moss (Table 2), but relatively abundant and common were also Tectocepheus velatus (Michael, 1880), Oribatula sp. 1, Achipteria nitens (Nicolet, 1855) and Brachychthonius berlesei Willmann, 1928. Moreover, Pillogalumna crassiclava (Berlese, 1914) was rather abundant in herbs under hawthorn, Metabelba macerochaeta Bulanova-Zachvatkina, 1967 in shrub litter under hawthorn, Sphaerochthonius splendidus (Berlese, 1904) in herbs under hawthorn with rose and Jacotella neonominata Subías, 2004 in herbs under elms.

In most oribatid communities, adults dominated, except for herbs and moss under hawthorn, where the juveniles were more abundant. This was mainly due to high densities of Trhypochthonius tectorum, Oribatula sp. 1 and Pillogalumna crassiclava, which were rich in juveniles. The age structure of species greatly depended on the type of vegetation (Table 2), which was well observed under hawthorn. In herbs, the density of juveniles of Oribatula sp. 1 was over 6-fold higher and in moss it was 2 -fold higher than the density of adults, while in shrub litter the adults dominated. The very abundant Trhypochthonius tectorum was rich in juveniles, while Chamobates c.f. spinosus was represented mostly by adults, which constituted $57-67 \%$ of its population.

\section{DISCUSSION}

The number of oribatid species in the coastal steppe vegetation of Crimea is relatively low (25-33 species), in comparison to the more elevated Crimean areas covered by forests, investigated by GordeEva (1973). She found 82 species in pine forest and 89 species in oak forest. The number of species of oribatid mites in coastal steppe is limited mainly by the dry steppe climate and vegetation, but the bushy patches protect to some degree the soil against intensive solar radiation, and increase the density of oribatid mites, as compared to open steppe vegetation (SENICZAK et al. 2009). For example, in moss under hawthorn the density was 11.6-fold higher than in moss under no cover. However, the species number of oribatid mites, and their Shannon index $H^{\prime}$ in bushes were comparable with those in open steppe vegetation. A fresh sea breeze lowers the coastal temperature and increases air humidity. This is important to oribatid mites, and therefore the oribatid mite communities of steppe vegetation of Crimea were richer in species than those from Rhodes Island, southern Andalusia, and Italy (Subías et al. 1985; Seniczak \& Seniczak 2006, 2010, 2011). 
Table 2. Characteristics of oribatid species in selected microhabitats under steppe bushes of Crimea: abundance $\left(A=\right.$ individuals per mean sample, i. e. $\left.500 \mathrm{~cm}^{3}, n=3\right)$ and dominance $(D=\%$ of the total number of oribatid mites in the mean sample). Species with maximum $A \leq 10$ are listed below the table

\begin{tabular}{|c|c|c|c|c|c|c|}
\hline \multirow{2}{*}{ Taxon } & & \multirow{2}{*}{$\begin{array}{l}\text { Elm, } \\
\text { herbs }\end{array}$} & \multicolumn{3}{|c|}{ Hawthorn } & \multirow{2}{*}{$\begin{array}{l}\text { Hawthorn+ } \\
\text { rose, herbs }\end{array}$} \\
\hline & & & & & litter & \\
\hline \multirow{2}{*}{$\begin{array}{l}\text { Achipteria nitens } \\
\text { (Nicolet, 1855) }\end{array}$} & $A$ & 2.0 & 351.0 & 107.0 & 403.0 & 257.3 \\
\hline & $D$ & 0.4 & 21.3 & 1.4 & 16.2 & 19.3 \\
\hline \multirow{2}{*}{$\begin{array}{l}\text { Pillogalumna crassiclava } \\
\text { (Berlese, 1914) }\end{array}$} & $A$ & 35.7 & 168.7 & 7.0 & 7.0 & 21.7 \\
\hline & $D$ & 6.9 & 10.3 & 0.1 & 0.3 & 1.6 \\
\hline \multirow{2}{*}{$\begin{array}{l}\text { Jacotella neonominata } \\
\text { Subías, } 2004\end{array}$} & $A$ & 68.0 & 0.3 & 0 & 0 & 10.3 \\
\hline & $D$ & 13.2 & $<0.1$ & 0 & 0 & 0.8 \\
\hline \multirow{2}{*}{$\begin{array}{l}\text { Brachychthonius berlesei } \\
\text { Willmann, } 1928\end{array}$} & $A$ & 0 & 126.0 & 4.0 & 126.7 & 249.0 \\
\hline & $D$ & 0 & 7.7 & 0.1 & 5.1 & 18.6 \\
\hline \multirow{2}{*}{$\begin{array}{l}\text { Chamobates c.f. spinosus } \\
\text { Sellnick, } 1928\end{array}$} & $A$ & 0.7 & 15.3 & 2980.0 & 926.0 & 2.7 \\
\hline & $D$ & 0.1 & 0.9 & 39.8 & 37.2 & 0.2 \\
\hline \multirow{2}{*}{$\begin{array}{l}\text { Licnodamaeus costula } \\
\text { Grandjean, } 1931\end{array}$} & $A$ & 56.0 & 4.7 & 0.3 & 0.3 & 0 \\
\hline & $D$ & 10.9 & 0.3 & $<0.1$ & $<0.1$ & 0 \\
\hline \multirow{2}{*}{$\begin{array}{l}\text { Metabelbella macerochaeta } \\
\text { Bulanova-Zachvatkina, } 1967\end{array}$} & $A$ & 7.3 & 48.3 & 8.3 & 83.7 & 69.7 \\
\hline & $D$ & 1.4 & 2.9 & 0.1 & 3.4 & 5.2 \\
\hline \multirow{2}{*}{ Oppiella sp. 1} & $A$ & 121.3 & 124.7 & 1.7 & 45.3 & 98.7 \\
\hline & $D$ & 23.5 & 7.6 & $<0.1$ & 1.8 & 7.39 \\
\hline \multirow{2}{*}{ Oribatula sp. 1} & $A$ & 66.3 & 539.7 & 480.7 & 242.3 & 152.3 \\
\hline & $D$ & 12.9 & 32.8 & 6.4 & 9.7 & 11.4 \\
\hline \multirow{2}{*}{$\begin{array}{l}\text { Passalozetes africanus } \\
\text { Grandjean, } 1932\end{array}$} & $A$ & 0 & 19.7 & 0 & 0 & 0 \\
\hline & $D$ & 0 & 1.2 & 0 & 0 & 0 \\
\hline \multirow{2}{*}{$\begin{array}{l}\text { Scheloribates laevigatus } \\
\text { (C. L. Koch, 1835) }\end{array}$} & $A$ & 32.7 & 66.0 & 7.0 & 4.7 & 3.3 \\
\hline & $D$ & 6.3 & 4.0 & 0.1 & 0.1 & 0.3 \\
\hline \multirow{2}{*}{$\begin{array}{l}\text { Sphaerochthonius splendidus } \\
\text { (Berlese, 1904) }\end{array}$} & $A$ & 20.3 & 60.7 & 11.0 & 131.3 & 122.0 \\
\hline & $D$ & 4.0 & 3.7 & 0.2 & 5.3 & 9.1 \\
\hline \multirow{2}{*}{$\begin{array}{l}\text { Tectocepheus velatus } \\
\text { (Michael, 1880) }\end{array}$} & $A$ & 44.3 & 52.3 & 1767.0 & 402.7 & 208.7 \\
\hline & $D$ & 8.6 & 3.2 & 23.6 & 16.2 & 15.6 \\
\hline \multirow{2}{*}{$\begin{array}{l}\text { Trhypochthonius tectorum } \\
\text { (Berlese, 1896) }\end{array}$} & $A$ & 0 & 0.7 & 2033.3 & 6.0 & 0 \\
\hline & $D$ & 0 & $<0.1$ & 27.2 & 0.2 & 0 \\
\hline
\end{tabular}

Bushy elms, herbs: Anachipteria sp. 1; Arthrodamaeus hispanicus Grandjean, 1928; Camisia horrida (Hermann, 1804); Cosmochthonius ponticus Gordeeva, 1980; C. reticulatus Grandjean, 1947; Ceratoppia quadridentata (Haller, 1882); Ceratozetes sp. 1; Cultroribula sp. 1; Damaeus sp. 1; Dorycranosus curtipilis (Willmann, 
1935); Eniochthonius minutissimus (Berlese, 1903); Eupelops acromios (Hermann, 1804); Eupelops sp. 1; Galumna sp. 1; Lucoppia burrowsi (Michael, 1890); Microppia minus (Paoli, 1908); Oppiella nova (Oudemans, 1902); Papillacarus aciculata (Berlese, 1905); Rhysortritia duplicata (Grandjean, 1953); Suctobelba sp. 1; Trichoribates incisellus (Kramer, 1897).

Hawthorn, herbs: Ceratoppia quadridentata; Ceratozetes sp. 1; Cosmochthonius ponticus; C. reticulatus; Eniochthonius minutissimus; Eupelops acromios; Eupelops sp. 1; Foseremaeus laciniatus (Berlese, 1905); Hermaniella punctulata (Berlese, 1908); Lucoppia burrowsi; Nothrus sp. 1; Passalozetes hispanicus Mihelčič, 1953; Scutovertex sp. 1; Synchthonius elegans Forsslund, 1957.

Hawthorn, moss: Camisia horrida; Cosmochthonius ponticus; C. reticulatus; Dorycranosus curtipilis; Eniochthonius minutissimus; Eupelops acromios; Eupelops sp. 1; Fosseremaeus laciniatus; Galumna sp. 1; Hermaniella punctulata; Micreremus brevipes (Michael, 1888); Oppiella sp. 2; Oribatula sp. 2; Phauloppia sp. 1; Trichoribates trimaculatus (C. L. Koch, 1835); Synchthonius elegans.

Hawthorn litter alone: Camisia segnis (Hermann, 1804); Chamobates sp. 1; Cosmochthonius ponticus; C. reticulatus; Dorycranosus curtipilis; Eniochthonius minutissimus; Eupelops sp. 1; Fosseremaeus laciniatus; Galumna sp. 1; Hypochthonius rufulus C. L. Koch, 1835; Nothrus sp. 1; Papillacarus aciculata; Passalozetes hispanicus; Phthiracarus 1; Rhysortritia duplicata; Suctobelba sp. 1; Suctobelba sp. 2; Synchthonius elegans; Trichoribates trimaculatus; Trimalaconothrus sp. 1.

Hawthorn with rose, herbs: Aphelacarus acarinus (Berlese, 1910); Arthrodamaeus hispanicus; Austrocarabodes sp. 1; Ceratoppia quadridentata; Compactozetes sp. 1; Cosmochthonius ponticus; Dorycranosus curtipilis; Eniochthonius minutissimus; Eupelops acromios; Eupelops sp. 1; Galumna sp. 1; Hermaniella punctulata; Hypochthonius rufulus; Lucoppia burrowsi; Oppiella sp. 2; Papillacarus aciculata; Passalozetes hispanicus; Protoribates capucinus Berlese, 1908; Punctoribates sp. 1; Rhysortritia duplicata; Suctobelba sp. 1; Synchthonius elegans.

In communities of oribatid mites, 3-4 species achieved high densities and dominance indices. This indicates, in the light of THIENEMANN's (1939) principles, a rather low soil fertility, probably due to a low precipitation. For example, in moss, 3 most abundant species (Chamobates c.f. spinosus, Tectocepheus velatus and Trhypochthonius tectorum) comprised over $90 \%$ of total oribatid mites, while in shrub litter, Chamobates c.f. spinosus, Tectocepheus velatus and Achipteria nitens comprised nearly $70 \%$ of all oribatid mites.

In open steppe vegetation, T. velatus usually dominated, Trhypochthonius tectorum was abundant only in patches of Sedum, Oribatula spp. was rather abundant in moss and other grasses, while Chamobates c.f. spinosus was absent (SENICZAK et al. 2009). Tectocepheus velatus is a cosmopolitan species (NüBEL-REIDELBACH 1994), and can be abundant both in extremely dry and extremely wet habitats (RAJSKI 1968), very much like Trhypochthonius tectorum. Genus Oribatula was also abundant in cypress litter in Caserta (Italy) and in moss from forest floor in Korčula (Croatia) (SEniczak \& Seniczak 2011; Seniczak et al. 2011).

In populations of most species of oribatid mites, the adults dominated, but the age structure depends on vegetation type. The participation of juveniles of Oribatula spp. and Trhypochthonius tectorum was higher than in open steppe vegetation (SENICZAK et al. 2009), but in Tectocepheus velatus it was similar, which well demonstrates the adaptation of $T$. velatus to arid climate (RAJSKI 1968).

All the species listed in Table 2 were already earlier recorded from Caucasus and Crimea (KARPPINEn et al. 1987; SENICZAK et al. 2009), but Dorycranosus curtipilis Willmann, 1935 and Papillacarus aciculata (Berlese, 1905) are new species for Crimea. All the papers included the endemic Crimean species Cosmochthonius ponticus Gordeeva, 1980. 
Table 3. Age structure of some oribatid species in selected microhabitats under steppe bushes of Crimea: mean density (individuals per $500 \mathrm{~cm}^{3}, \mathrm{n}=3$ ) of juveniles (Juv) and adults (Ad)

\begin{tabular}{l|l|r|r|r}
\hline \multirow{2}{*}{ Species } & Microhabitat & \multicolumn{1}{c}{ Juv } & \multicolumn{1}{c}{ Ad } & Total \\
\hline \multirow{3}{*}{ Achipteria nitens } & Hawthorn litter alone & 174.0 & 229.0 & 403.0 \\
& Hawthorn, herbs & 181.7 & 169.3 & 351.0 \\
Pillogalumna crassiclava & Hawthorn, moss & 73.0 & 34.0 & 107.0 \\
& Hawthorn, herbs & 144.0 & 24.7 & 168.7 \\
Brachychthonius berlesei & Elm, herbs & 24.7 & 11.0 & 35.7 \\
Chamobates c.f. spinosus & Hawthorn and rose, herbs & 128.3 & 120.7 & 249.0 \\
& Hawthorn litter alone & 72.7 & 54.0 & 126.7 \\
Metabelbella macerochaeta & Hawthorn, moss & 1296.0 & 1684.0 & 2980.0 \\
& Hawthorn litter alone & 306.7 & 619.3 & 926.0 \\
& Hawthorn litter alone & 21.4 & 62.3 & 83.7 \\
Oribatula sp. 1 & Hawthorn and rose, herbs & 14.0 & 55.7 & 69.7 \\
Sphaerochthonius splendidus & Hawthorn, herbs & 3.3 & 45.0 & 48.3 \\
& Hawthorn, herbs & 465.4 & 74.3 & 539.7 \\
Tectocepheus velatus & Hawthorn, moss & 322.7 & 158.0 & 480.7 \\
& Hawthorn litter alone & 119.3 & 123.0 & 242.3 \\
Trhypochthonius tectorum & Hawthorn and rose, herbs & 26.0 & 105.3 & 131.3 \\
& Hawthorn litter alone & 36.7 & 85.3 & 122.0 \\
& Hawthorn and rose, herbs & 940.7 & 1226.3 & 1767.0 \\
& Hawthorn, moss & 1776.0 & 257.3 & 2033.3 \\
\hline
\end{tabular}

\section{CONCLUSIONS}

1. The density of oribatid mites in bushy patches of cape Tarkhankut was distinctly higher, but the species number was similar like in open steppe vegetation. Hawthorn increased the density distinctly more than hawthorn with rose or elms; moss was richer in mites than patches of shrub litter alone or herbs.

2. In bushy patches the most abundant were Chamobates c.f. spinosus and Trhypochthonius tectorum, but relatively abundant and common were also Tectocepheus velatus, Oribatula sp. 1, Achipteria nitens and Brachychthonius berlesei.

3. In oribatid mite communities the adults usually dominated, but the age structure of species greatly depended on vegetation type.

\section{REFERENCES}

GordEEva E. V. 1973. Fauna pancirnych kleščej gornogo Kryma [Fauna of oribatid mites of Higher Crimea]. Ecology of soil invertebrates, Nauka, Moskva (in Russian). 
Gordeeva E. V. 1980. Pancirnyje klešči semejstva Cosmochthoniidae (Oribatei) [Oribatid mites of family Cosmochthoniidae (Oribatei)]. Zool. Zh. 59: 838-850 (in Russian).

GordeEva E. V. 1983. Pancirnyje klešči roda Quadroppia (Oribatei, Oppiidae) iz raznych rajonov Sovetskogo Sojuza [Oribatid mites of the genus Quadroppia (Oribatei, Oppiidae) from various regions of the Soviet Union]. Zool. Zh. 62: 1267-1270 (in Russian).

GordeEva E. V., Karppinen E. 1988. New oribatid mites of the family Oppiidae Grandjean, 1954 (Acarina, Oribatei) from Crimea and Caucasus. An. Entomol. Fen. 54: 59-64.

Gordeeva E. V., Niemi R., Petrova-Nikitina A. D. 1998. A new genus and species, Tauroplophora aureonatata, from the Crimea, Ukraine, and a new species, Cryptoplophora asiatiaca, from Turkmenistan (Acari, Oribatida, Protoplophoridae). Acarologia 39: 185-190.

Karppinen E., Krivoluckij D. A., Tarba Z. M., Shtanchaeva U. Ya, Godreeva E. W. 1987. List of oribatid mites (Acarina, Oribatei) from northern Palaearctic region. IV. Caucasus and Crimea. An. Entomol. Fen. 53: 119-137.

Nübel-Reidelbach E. 1994. Taxonomie und Systematik der Gattung Tectocepheus Berlese, 1895 [Taxonomy and systematic of Tectocepheus Berlese, 1895]. Andrias 12: 3-94 (in German).

Odum E. P. 1971. Fundaments of ecology. W. B. Saunders Co., Georgia.

RAJSKI A. 1967. Autecological-zoogeographical analysis of moss mites (Acari, Oribatei) on the basis of fauna in the Poznan Environs. Part I. Bull. Entomol. Pol. 37: 69-166.

RAJSKI A. 1968. Autecological-zoogeographical analysis of moss mites (Acari, Oribatei) on the basis of fauna in the Poznań environs. Part. II. Fragm. Faun. 14: 277-405.

Seniczak S., Kaczmarek S., Seniczak A. 2009. Oribatid mites (Acari, Oribatida) of steppe vegetation on cape Tarkhankut in Crimea (Ukraine). Biological Lett. 46: 43-49.

Seniczak S., Kaczmarek S., Seniczak A. 2011. Oribatid mites (Acari, Oribatida) of selected habitats of Korčula (Croatia). Biological Lett. (in press).

Seniczak S., SenicZak A. 2006. Oribatid mites (Acari) of some habitats of Rhodes Island (Greece). Biological Lett. 43: 215-219.

Seniczak S., Seniczak A. 2010. Oribatid mites (Acari, Oribatida) of selected habitats of south part of Andalusia (Spain). Biological Lett. 47: 29-35.

Seniczak S., Seniczak A. 2011. Oribatid mites (Acari, Oribatida) of selected habitats of southern Italy. Biological Lett. (in press).

Subías L. S. 2004. Listado sistemático, sinonímico y biogeográfico de los Ácaros Oribátidos (Acariformes, Oribatida) del mundo (1758-2002) [Systematic, synonymic and biogeographical check-list of the world's oribatid mites (Acariformes, Oribatida) (1758-2002)]. Graellsia 60: 3-305 (in Spanish). Online version accessed in February 2011, http://www.ucm.es/info/zoo/ Artropodos/Catalogo.pdf.

Subías L. S., Ruiz E., Minguez M. E. 1985. Aportación al conocimiento de las comunidades de Oribatidos (Acari) del erial mediterráneo [Contribution to the knowledge of the communities of Oribatida (Acari) from the Mediterranean heath]. Actas do II Congresso Ibérico de Ent. 1: 389-398 (in Spanish).

Thienemann A. 1939. Grundzüge einer allgemainen Oecologie [Principle of general ecology]. Arch. Hydrobiol. 35: 267-285 (in German).

Weigmann G. 2006. Hornmilben (Oribatida) [Oribatid mites (Oribatida)]. In: Die Tierwelt Deutschland und der angrenzenden Meeresteile. 76. Teil (DAHL F., Ed.), pp. 1-520, Goecke \& Evers, Keltern (in German). 